\title{
Agricultural reuse: comparison between Brazilian and international quality standards
}

\begin{abstract}
Reused water is increasingly requested by farmers worldwide, but there is no legislation in Brazil that contains all the parameters for assessing its quality. This study aimed to compare the legal provisions in Brazil related to the quality parameters of reused water for agriculture (microbiological, physical and chemical) with those described in the main regulations of the United States, drawing a parallel with the Brazilian reality. The study is descriptive, based on queries and collections of regulations in electronic documentary data source on Google Scholar. The existing parameters described in the Brazilian regulations for agricultural reuse have been compared with the standards established in the international regulations of the United States Environmental Protection Agency and the World Health Organization. The main results showed that there is a discrepancy between internationals and Brazilian legislations according to physical, chemical and microbiological parameters. Therefore, the work suggests a creation of new Brazilian legislations about agricultural reuse whereas the control of hydraulic pollutants and water reuse is immature comparing to internationals levels.
\end{abstract}

Keywords: water reuse, agricultural reuse, water quality, legislations, Brazilian standards, public health
Volume 5 Issue I - 202 I

\author{
Natasha Berendonk Handam,' Ana Beatriz \\ Loureiro Gonçalves da Silva, ${ }^{2}$ Adriana \\ Sotero-Martins, ${ }^{3}$ José Augusto Albuquerque \\ dos Santos ${ }^{4}$ \\ 'Program of Doctor's Degree in Public Health and Environment, \\ Sergio Arouca National School of \\ Public Health, Oswaldo Cruz Fundation (ENSP/FIOCRUZ), Rio \\ de Janeiro, RJ, Brazil \\ ${ }^{2}$ Chemical Engineering Graduate Student, Senai CETIQT, PIBIC/ \\ CNPQ Scholarship, Rio de Janeiro, RJ, Brazil \\ ${ }^{3}$ Department of Sanitation and Environmental Health, Sergio \\ Arouca National School of Public \\ Health, Oswaldo Cruz Fundation (DSSA/ENSP/FIOCRUZ), Rio \\ de Janeiro, RJ, Brazil \\ ${ }^{4}$ Laboratory for Assessment and Promotion of Environmental \\ Health, Oswaldo Cruz Institute, Oswaldo Cruz Fundation (IOC/ \\ FIOCRUZ), Rio de Janeiro, RJ, Brazilx
}

\begin{abstract}
Correspondence: Natasha Berendonk Handam, Program of Doctor's Degree in Public Health and Environment, Sergio Arouca National School of Public Health, Oswaldo Cruz Fundation (ENSP/FIOCRUZ), Rua Leopoldo Bulhões, 1480 Manguinhos, Rio de Janeiro, RJ, Brazil, Email natashabhanda@gmail.com
\end{abstract}

Received: January 26, 2021 | Published: Febrauary 08, 2021

\section{Introduction}

Amid the scarcity of fresh water in several regions in Brazil and worldwide, the water reuse resulting from the reutilization of water from treated effluents ${ }^{1,2}$ becomes an alternative source of water for agriculture, for example. ${ }^{3}$ Agriculture is the activity that most consumes fresh water in the world, reaching a consumption of about $70 \%{ }^{4}$ The use of water reuse in agriculture can bring benefits such as nutrients and water, favoring the growth of plants and reducing the use of artificial fertilizers. ${ }^{5}$ However, water reuse must be well managed and with adequate quality, so that it does not pose risks to human and environmental health, ${ }^{6}$ as it may contain pathogens such as protozoa, bacteria, viruses, helminths, and the high presence of salts. ${ }^{7,8}$ Thus, for the proper and safe use of water reuse for agricultural irrigation, it is essential to analyze its physical, chemical and microbiological quality. ${ }^{5}$ The water reuse can be classified according to its origin, in: local or internal reuse, the water reuse obtained from the gray water treatment from the residential reuse; and external reuse, from black waters that pass through a sewage treatment plant and from reused water (ETE + WWTP). ${ }^{1}$ Agricultural reuse can be included in these two classifications, from gray or black waters. It is estimated that $40 \%$ of the world population will live in countries that face water stress or water scarcity in the next 50 years. ${ }^{6}$ The use of water reuse for irrigation helps to reduce environmental impacts, as it represents an alternative to reduce the pressure of demand on the springs and reduce the amount of sewage discarded. ${ }^{9}$ However, the use of water reuse can offer negative impacts, such as acting as a vehicle for transmitting diseases to people who come into contact with it, depending on the quality of the water reuse. However, adequate management planning can bring benefits, considering that negative impacts can be reduced through good agricultural practices. ${ }^{6}$

In general, countries have sought to expand the regulation and monitoring of pollutants and contaminants that were not the object of attention by legal provisions, for the reuse of wastewater. ${ }^{5}$ The United States is more advanced when it comes to the quality of water bodies, many states adopt guidelines for the use of water reuse, encouraging new uses, such as irrigation in agriculture. In Brazil, there is still no specific federal legislation that addresses the use of reused water, establishing criteria and parameters, such as biological and physical and chemical ones for assessing the water reuse quality for agriculture. There are only regulations in some Brazilian states. This reflects the low maturity of the Brazilian system regarding the control of pollutants and water contaminants, and the use of wastewater. Internationally, there are regulations such as those of the United States Environmental Protection Agency (EPA) of 2012, and the World Health Organization (WHO) of 2006, which deal more fully with reuse water for agriculture, with physical, chemical and biological parameters, based on in scientific studies, so that this water becomes safer for those who use it. The aim of this study was to compare the legal provisions in Brazil regarding the parameters of quality of water reuse for agriculture (microbiological, physical and chemical) with 
those described in the main regulations of the United States, drawing a parallel with the Brazilian reality.

\section{Materials and methods}

This was a descriptive study, based on consultations and collections of standards in electronic documentary data source at Google Scholar, from March 2018 to October 2020. For the eligibility criteria used for the inclusion of Brazilian standards, the standards in effect until the consultation period were considered, and that had described quality parameters (microbiological, physical and chemical) for agricultural reuse: Brazilian nationals (federal, state and municipal levels). The following descriptors were used: in the Portuguese language of Brazilian territory, "água de reúso e agricultura", "reúso agrícola", "uso de águas residuais". The exclusion criteria were those that did not have microbiological, physical and chemical quality parameters, and that contained the terms and keywords in the Brazilian Portuguese language "água de chuva", "água pluvial", "água reciclada". Brazil observes the international standards of the United States of America to assist in the development of Brazilian water reuse quality standards for agriculture, because physical, chemical and microbiological parameters are established based on scientific studies. The American regulations considered in the comparison of this study were: "Guidelines for Water Reuse" by United States Environmental Protection Agency - EPA, ${ }^{5}$ and "Guidelines for the safe use of wastewater, excreta and graywater" by the World Health Organization - WHO. ${ }^{6}$ The Brazilian norms found with quality standards were: Norm of the Brazilian Association of Technical Norms (ABNT) NBR 13969/97: ${ }^{10}$ State Resolution of the State Water Resources Council (CONERH) of Bahia $\mathrm{n}^{\circ} 75$ of $2010 ;{ }^{11}$ and Resolution of the State Environmental Council (COEMA) of Ceará $n^{\circ} 2$ of February 2, 2017. ${ }^{12}$ The existing parameters described in the Brazilian regulations on agricultural reuse mentioned above were compared with the standards established in the international regulations of the $\mathrm{EPA}^{5}$ and $\mathrm{WHO},{ }^{6}$ which were the physical and chemical parameters listed in Table 1 , and the microbiological parameters (total coliforms, thermotolerant coliforms, and helminths).

\section{Results and discussion}

In Brazil, few laws were found for the application of reused water however they did not have standards for assessing the water reuse quality. There is the Resolution of the National Water Resources Council (CNRH) no 54, of November 28, 2005, which establishes general modalities, guidelines and criteria to regulate and encourage the practice of direct non-potable water reuse, throughout the national territory. Specifically on agricultural reuse, in its Art. 3 the law deals with the modalities of direct non-potable water reuse, and among these one modality refers to the use for agriculture: "II - reuse for agricultural and forestry purposes: application of water reuse for agricultural production and cultivation of planted forests". ${ }^{13}$ This regulation only establishes the type of use of water reuse in agriculture, but does not provide other guidelines on the subject. On December 16, 2010, CNRH Resolution No. 121 established the guidelines and criteria for the practice of direct non-potable water reuse in agricultural and forestry, defined in Resolution CNRH No. 54, of November 28, 2005. This standard contains specific information about water reuse in agriculture and in the cultivation of planted forests. However, it does not deal with the standards for the evaluation of the quality of water reuse for agriculture, it only states that "the physical, chemical and biological characteristics for water in all types of reuse for agricultural and forestry purposes must meet the defined limits relevant legislation". ${ }^{14}$ In this standard it is presented that the use of the water reuse for agricultural and forestry purposes cannot offer risks or cause environmental damage and public health. It is evident that it is a national norm that is incipient, and needs to provide more information and establish the parameters and methods for assessing the water reuse sanitary quality and the soil that receives it for agriculture and for the cultivation of planted forests.

There are few regulations about water reuse with quality standards, which makes it difficult to use this water resource safely in Brazilian territory, without causing risks to public health. Only specific regulations of some Brazilian states were found, which contain the microbiological, physical and chemical quality parameters of the water reuse for agriculture. These are the laws: Standard of the Brazilian Association of Technical Standards (ABNT) NBR $13969 / 97 ;{ }^{10}$ State Resolution of the State Water Resources Council (CONERH) of Bahia $n^{\circ} 75$ of $2010 ;{ }^{11}$ and Resolution of the State Environmental Council (COEMA) of Ceará $n^{\circ} 2$ of February 2, 2017. ${ }^{12}$ Regarding microbiological parameters, the norm of the Brazilian Technical Standards Association (ABNT) NBR 13969/97, ${ }^{10}$ deals in class 4 about the reuse in orchards, cereals, forages, pastures for cattle and other crops through runoff or by punctual irrigation system. This standard determines that the limit of thermotolerant coliforms must be less than 5,000/100 ml. Another rule is the State Resolution of the State Water Resources Council (CONERH) of Bahia $\mathrm{n}^{\circ} 75$ of $2010,{ }^{11}$ which determines a limit value for thermotolerant coliforms of 1,000/100 $\mathrm{ml}$ for category A (Irrigation, including hydroponics, of any culture including food products consumed raw), and 10,000/100 $\mathrm{ml}$ for drip irrigation; and 10,000/100 $\mathrm{ml}$ of thermotolerant coliforms for category B (Irrigation, including hydroponics, of uneaten raw food products, non-food products, forages, pastures, trees, crops used in revegetation and recovery of degraded areas). There is also in Brazil the Resolution of the State Council for the Environment (COEMA) of Ceará $\mathrm{n}^{\circ} 2$ of February 2, 2017.12 This standard determines that there must be an absence of thermotolerant coliforms in cultures to be consumed raw whose part consumed has direct contact with irrigation water. For other cultures, the water must contain up to $1,000 / 100 \mathrm{ml}$ of total coliforms. The law also deals with geohelminth eggs in cultures to be consumed raw in direct contact with irrigation water, and there must be no eggs, but the other forms can contain up to 1 geohelminth egg/l of water reuse sample. ${ }^{12}$

According to EPA, ${ }^{5}$ the water must have a concentration of thermotolerant coliforms of up to $200 / 100 \mathrm{ml}$, and in the irrigation of crops by sprinkling there must be an absence of thermotolerant coliforms. For uses in which water is likely to have direct or indirect contact, disinfection is recommended to produce water reuse without detectable fecal coliforms per $100 \mathrm{ml}$ using filtration as a method. For indirect uses, disinfection is recommended to produce water reuse without total detectable coliforms per $100 \mathrm{ml}$. In WHO (2006) the biological quality parameters are: Irrigation of crops that are eaten raw, sports fields and public parks must have $\leq 1$ nematode egg/l and $\leq 1000$ thermotolerant Coliforms $/ 100 \mathrm{ml}$; Irrigation of cereal crops, to be industrialized, forage, pastures and trees must have $\leq 1$ nematode egg/l. It was found that the levels of thermotolerant coliforms of the aforementioned Brazilian standards are above the level determined by the EPA. ${ }^{5}$ Regarding WHO regulations, ${ }^{6}$ the law of Bahia has the same values of coliforms, and the law of Ceará determines more restrictive values. The ABNT 13969/97 standard ${ }^{10}$ recommends a limit value above that determined by international regulations. 
Regarding the physical and chemical parameters (Table 1), according to State Resolution No. 75 of $2010,{ }^{11}$ the value for electrical conductivity is up to $3.0 \mathrm{dS} / \mathrm{m}$, and in the Resolution of the State Environmental Council (COEMA ) $\mathrm{n}^{\mathrm{o}} 2$ of 02 February $2017^{12}$ the value is up to $3000 \mathrm{dS} / \mathrm{cm}$. While in the EPA standard, ${ }^{5}$ as well as $\mathrm{WHO}^{6}$ for electrical conductivity, values below $0.7 \mathrm{dS} / \mathrm{m}$ are not at risk, from $0.7 \mathrm{dS} / \mathrm{m}$ to $3.0 \mathrm{dS} / \mathrm{m}$ is moderate and values $>3 \mathrm{dS} / \mathrm{m}$ are high risk. The electrical conductivity indirectly indicates the total concentration of salts in the water, and is usually the parameter chosen to check the salinity of the water. ${ }^{5}$ The greater the electrical conductivity, the greater the degree of salinity and the ability of water to infiltrate the soil, which affects water availability for agricultural crops. ${ }^{5}$ Brazilian regulations are less restrictive compared to international standards. The Bahia State Resolution 75/2010, allows a limit of electrical conductivity considered moderate for EPA and WHO, and the Resolution of COEMA 2/2017 has a limit 1,000 times higher than that allowed by international laws.

Table I Maximum permitted values of the physical and chemical parameters of the Brazilian regulations on agricultural reuse in comparison with the U.S. standards. Standards: Bahia CONERH Resolution No. 75/2010; Ceará State Resolution No. 2/20I7; EPA - U.S. Environmental Protection Agency; Guidelines for water reuse, 2012;WHO - World Health Organization. Guidelines for the safe use of wastewater, excreta and graywater, 2006

\begin{tabular}{|c|c|c|c|c|}
\hline Parameters & BAHIA(20I0) & CEARÁ (2017) & WHO (2003) & EPA (20|2) \\
\hline $\mathrm{pH}$ & ND & $6,0-8,5$ & $6,6-7,0$ & $6,0-9,0$ \\
\hline Electric conductivity $(\mathrm{dS} / \mathrm{cm})$ & 3,0 & 3000 & $<0,7(B) ; 0,7-3,0(M) ;>3(A)$ & $<0,7(\mathrm{~B}) ; 0,7-3,0(\mathrm{M}) ;>3(\mathrm{~A})$ \\
\hline Chloride (meq/l) & $100-350$ & ND & $>3$ & $<4(\mathrm{~B}) ; 4-0(\mathrm{M}) ;>10(\mathrm{~A})$ \\
\hline Lead (mg/l) & 5,00 & ND & 5,00 & 5,00 \\
\hline Aluminum (mg/l) & 5,00 & ND & 5,00 & 5,00 \\
\hline Arsenic (mg/l) & 0,10 & ND & 0,10 & 0,10 \\
\hline Beryllium (mg/l) & 0,10 & ND & 0,10 & 0,10 \\
\hline Boron (mg/l) & 0,5 & ND & ND & 0,75 \\
\hline Cadmium (mg/l) & 0,01 & ND & ND & 0,01 \\
\hline Copper (mg/l) & 0,20 & ND & 0,20 & 0,20 \\
\hline Chromium (mg/l) & 0,1 & ND & 0,1 & 0,1 \\
\hline Iron (mg/l) & 5 & ND & 5 & 5 \\
\hline Fluoride (mg/l) & I & ND & I & I \\
\hline Lithium (mg/l) & 2,50 & ND & 2,50 & 2,50 \\
\hline Manganese (mg/l) & 0,20 & ND & 0,20 & 0,20 \\
\hline Mercury (mg/l) & 0,002 & ND & ND & 0,002 \\
\hline Molybdenum (mg/l) & 0,01 & ND & 0,01 & 0,01 \\
\hline Nickel (mg/l) & 0,02 & ND & 0,02 & 0,02 \\
\hline Sodium (mg/l) & 70 & ND & $<3(\mathrm{~B}) ;>3(\mathrm{M})<3(\mathrm{~B}) ; 3-9(\mathrm{M}) ;>9(\mathrm{~A})$ & 70 \\
\hline
\end{tabular}

ND, There are no standards described in the laws; $B$, low risk; $M$, moderate risk; $A$, high risk

As for the recommended range of standard value for $\mathrm{pH}$ in Ceará Resolution 2/2017, being 6.0-8.5. In the Bahia standard it does not have a standard value for $\mathrm{pH}$. While in $\mathrm{EPA}^{5}$ the permitted range is slightly lower, being 6.0-8.4, and in $\mathrm{WHO}^{6}$ the $\mathrm{pH}$ range is 6.5-7.0. The standard established for $\mathrm{pH}$ by the Bahia standard is similar to the EPA standard. There are other physical and chemical parameters for agricultural reuse in Brazil, which are established in State Resolution No. 75 of $2010,{ }^{11}$ which are chloride with a limit range of 100 to 350 meq/l; Aluminum up to $5 \mathrm{mg} / \mathrm{l}$, Arsenic up to $0.10 \mathrm{mg} / \mathrm{l}$, Beryllium up to $0.10 \mathrm{mg} / 1$, Boron up to $0.5 \mathrm{mg} / \mathrm{l}$, Cadmium up to $0.01 \mathrm{mg} / \mathrm{l}$, Lead up to $5.00 \mathrm{mg} / 1$, Cobalt up to $0.05 \mathrm{mg} / 1$, Copper up to $0.20 \mathrm{mg} / \mathrm{l}$, Chromium up to $0.1 \mathrm{mg} / 1$, Iron up to $5 \mathrm{mg} / \mathrm{l}$, Fluoride up to $1.00 \mathrm{mg} / \mathrm{l}$, Lithium up to $2.50 \mathrm{mg} / \mathrm{l}$, Manganese up to $0.20 \mathrm{mg} / \mathrm{l}$, Mercury up to $0.002 \mathrm{mg} / 1$, Molybdenum up to $0.01 \mathrm{mg} / \mathrm{l}$, Nickel up to $0.20 \mathrm{mg} / \mathrm{l}$,
Selenium up to $0.02 \mathrm{mg} / \mathrm{l}$, Sodium up to $70,0 \mathrm{mg} / \mathrm{l}$, Vanadium up to $0.10 \mathrm{mg} / \mathrm{l}$ and Zinc up to $2 \mathrm{mg} / \mathrm{l}$.

According to EPA, ${ }^{5}$ chloride in surface irrigation for values $<4$ $\mathrm{meq} / \mathrm{l}$ does not present risks, from 4 to $10 \mathrm{meq} / \mathrm{l}$ the risk is moderate and $>10 \mathrm{meq} / \mathrm{l}$ the risk is high; for sprinkler irrigation, values below $3 \mathrm{meq} / \mathrm{l}$ do not present risks and above $3 \mathrm{meq} / \mathrm{l}$ the risk is moderate; Fluoride up to $5.00 \mathrm{mg} / \mathrm{l}$; Lead up to $1.00 \mathrm{mg} / 1$; Boron up to $0.75 \mathrm{mg} / \mathrm{l}$. The other physical-chemical parameters presented in $\mathrm{EPA}^{5}$ have the same values as those presented above established in State Resolution No. 75 of 2010, this regulation being in accordance with international law. According to $\mathrm{WHO},{ }^{6}$ chloride in surface irrigations for values $<3 \mathrm{meq} / 1$ do not present risks, and $>3 \mathrm{meq} / \mathrm{l}$ present a risk of mild to moderate. The other physical and chemical parameters presented by this international standardization are the same values of State 
Resolution No. 75 of 2010, with the exception of Boron, Cadmium and Mercury that do not have standards; and Sodium which for sprinkler irrigation values $<3 \mathrm{meq} / 1$ do not present risks and values $>3$ $\mathrm{meq} / \mathrm{L}$ present risks; for surface irrigation, values $<3 \mathrm{meq} / \mathrm{L}$ are not at risk, 3 to $9 \mathrm{meq} / \mathrm{L}$ are moderate and above $9 \mathrm{meq} / \mathrm{L}$ are at high risk. ${ }^{11}$

It was found that except for the parameters $\mathrm{pH}$, electrical conductivity, chloride, and boron, the other physical and chemical parameters existing in Brazilian regulations for agricultural reuse are with maximum permitted values similar to the standards of the international laws $\mathrm{EPA}^{5}$ and WHO. ${ }^{6}$ The chloride parameter of the Brazilian legislation is higher than the limit recommended by the referred international laws, being considered a high risk to health. The boron parameter is lower than the value established by the international law EPA, ${ }^{5}$ and in $\mathrm{WHO}^{6}$ it does not present an established standard. For this standard, free residual chlorine can be present as a disinfection residue, and in concentrations below 1 $\mathrm{mg} / \mathrm{L}$, it generally does not present problems for plants; chlorine in concentrations above $5 \mathrm{mg} / \mathrm{L}$ can cause severe damage to most plants. However, some sensitive cultures can be damaged at levels as low as $0.05 \mathrm{mg} / \mathrm{L}$. According to WHO, ${ }^{6} \mathrm{STD}$ values below $450 \mathrm{mg} / \mathrm{L}$ are not at risk; values between 450 and $2000 \mathrm{mg} / \mathrm{L}$ present a risk of mild to moderate; and values above $2000 \mathrm{mg} / \mathrm{L}$ present severe risks. In addition, the recommendation proposed by $\mathrm{WHO}^{6}$ establishes values for the chlorine parameter in which $<4 \mathrm{meq} / \mathrm{L}$ is not at risk, from 4 to $10 \mathrm{meq} / \mathrm{L}$ is at risk of mild to moderate and $>10 \mathrm{meq} / \mathrm{L}$ is at high risk.

\section{Conclusion}

There are few laws in Brazil about water reuse quality standards, as well as for agricultural reuse. Existing Brazilian regulations are less restrictive compared to international standards. Bahia's CONERH Resolution No. 75/2010 was the most complete in terms of microbiological, physical and chemical quality parameters. In this law, the quality standards of most physical and chemical parameters are similar to the international standard established in Guidelines for water reuse - EPA, and the microbiological parameters are the same established in Guidelines for the safe use of wastewater, excreta and greywater - WHO. However, in ABNT Standard 13969/97, which is the only federal regulation that has quality standards for the use of reused water, it recommends different limit values and above that determined by international regulations, being less restrictive. In addition, the inexistence in the Brazilian system of control of pollutants and water contaminants to safely carry out the use of wastewater, leads to believe in the need to create legislation at national level for agricultural reuse. In federal law, it must contain information on the origin of water, health quality standards, physical, chemical and biological parameters, and forms of treatment for its production, as well as standardized in international legislation, which are more developed with respect to the quality of bodies avoiding damage to human and environmental health.

\section{Acknowledgments}

Acknowledgments to the National Council for Scientific and Technological Development - CNPq; the Research Support
Foundation of the State of Rio de Janeiro - FAPERJ; Post Graduate Support Program from the Coordination for Improvement of Higher Education Personnel - PROAP / CAPES, and the Sergio Arouca National School of Public Health - ENSP, Oswaldo Cruz Foundation - FIOCRUZ.

\section{Conflicts of interest}

The authors have no conflicts of interest to declare.

\section{References}

1. Moura PG, Salles MJ, Carvajal E, et al. Concepts and classification for water reuse in Brazil by different destinations. American Journal of Engineering Research (AJER). 2019;8(8):156-159.

2. Morais MA, Ferreira Neto M, Silva GF, et al. Contaminação microbiológica no perfil do solo por águas residuárias. HOLOS. 2016;3:76-83.

3. Mancuso PCS, Santos HF. Reúso de Água. 1th ed. São Paulo: Manole Editorial; 2013 .

4. WHO, Word Health Organization. Water Security \& the Global Water. Agenda AUN-Water Analytical Brief. Canada: 2013.

5. EPA, United States Environmental Protection Agency. Guidelines for water reuse. Washington: 2012.

6. WHO, World Health Organization. Guidelines for the safe use of wastewater, excreta and greywater. Wastewater use in agriculture. Geneva: 2006.

7. Jaramillo MF, Restrepo I. Wastewater Reuse in Agriculture: A Review about Its Limitations and Benefits. Sustainability. 2017;9(10):1734-1753.

8. Silva ÁFS, Lima CA, Queiroz JJF, et al. Bacteriological analysis of horticultural irrigation water. Ambiente e Agua - An Interdisciplinary Journal of Applied Science. 2016;11(2):428-437.

9. Urkiaga A, Fuentesa L, Bisb B., et al. Development of analysis tools for social, economic and ecological effects of water reuse. Desalination. 2008;218:81-91.

10. ABNT, Associação Brasileira de Normas Técnicas. NBR 13.969 de 30 de outubro de 1997. Unidades de tratamento complementar e disposição final dos efluentes líquidos. Brazil: 1997.

11. Bahia (Estate). Resolução CONERH $n^{\circ} 75$ de 29 de julho de 2010 Estabelece modalidades, diretrizes e critérios gerais para prática de reúso direto não potável de água. Diário oficial da União; Bahia, Brazil, 2010.

12. Ceará (Estate). Resolução do Conselho Estadual do Meio Ambiente (COEMA) $n^{\circ}$ 2, de 02 de fevereiro de 2017. Dispõe sobre padrões e condições para lançamento de efluentes líquidos gerados por fontes poluidoras. Diário oficial da União; Ceará, Brazil, 2017.

13. Brazil. Resolução CNRH $n^{\circ} 54$, de 28 de novembro de 2005. Brasília Brazil, 2006.

14. Brazil. Resolução CNRH $n^{\circ} 121$, de 16 de dezembro 2010. Brasília, Brazil 2010

15. Silva TL. Qualidade da água residuária para reuso na agricultura irrigada. Irriga, Botucatu. 2018;1(1):101-111. 